\title{
Effects of different thawing methods on the quality of meagre fillets
}

\author{
İsmail Yüksel GENÇ ${ }^{1}$, Eduardo ESTEVES ${ }^{2}$, Jaime ANÍBAL ${ }^{3}$, Abdullah DİLER $^{1}$ \\ ${ }^{1}$ Department of Fishing and Processing Technology, Faculty of Fisheries, University of Süleyman Demirel, Isparta, Turkey; \\ ${ }^{2}$ Departmento de Engenharia Alimentar, Instituto Superior de Engenharia, Universidade do Algarve and Centro de Ciências do Mar \\ CCMar - CIMAR Laboratório Associado, Faro, Portugal; ${ }^{3}$ CIMA - Centro de Investigação Marinha e Ambiental and Departamento \\ de Engenheria Alimentar, Instituto Superior de Enginharia, Universidade do Algarve,Portugal.
}

Summary: The aim of this study was to determine the effect of different thawing methods (air, refrigerator, water and microwave) on physical, chemical and microbiological quality of meagre fillets which were frozen and stored at $-20^{\circ} \mathrm{C}$ for 21 days. The samples were compared for colour changes, $\mathrm{pH}$, total volatile basic nitrogen (TVB-N), hardness, adhesiveness, total viable count (TVC), total psychrophilic count (TPC) and hydrogen-sulphide producing bacteria $\left(\mathrm{H}_{2} \mathrm{~S}\right)$. In terms of hardness, refrigerator thawed samples exhibited a harder texture compared to other ones. Taking into account all parameters studied, refrigerator thawing was found to be more suitable for the frozen meagre fillets.

Key words: Frozen fish, Meagre (Argyrosomus regius), Quality, Thawing methods.

\section{Farklı çözdürme tekniklerinin sarıağız balığı filetolarının kalitesi üzerine etkileri}

Özet: $\mathrm{Bu}$ çalışmanın amacı dondurulmuş ve $-20^{\circ} \mathrm{C}$ 'de 21 gün muhafaza edilen sarıă̆ız balığı filetolarında farklı çözdürme tekniklerinin (hava, buzdolabı, su ve mikrodalga) fiziksel, kimyasal ve mikrobiyolojik etkilerinin belirlenmesidir. Örnekler, renk değişimleri, $\mathrm{pH}$, toplam uçucu bazik azot, sertlik, yapışkanlık, toplam canlı sayısı, toplam psikrofilik bakteri sayısı ve hidrojen sülfit üreten bakteri sayısı açısından karşılaştırılmışlardır. Sertlik açısından buzdolabında çözdürülen örnekler en yüksek değeri almıştır. Çalışılan bütün parametreler göz önüne alındığında dondurulmuş sarıă̆ız balığı filetoları için buzdolabında çözdürme en uygun metod olarak belirlenmiştir.

Anahtar sözcükler: Çözdürme metotları, Donmuş balık, Kalite, Sarıăız (Argyrosomus regius).

\section{Introduction}

Meagre, Argyrosomus regius (Asso, 1801) is a sciaenoid fish that is widespread in the Mediterranean Sea, Black Sea, Atlantic coast of Europe and west coast of Africa (11, 19, 36, 38). It is a highly valuable commercial fish species which is resistant to aquaculture conditions and changing environmental conditions (20, $34,36)$. Due to its size and shape, there is good potential for marketing of meagre fillets (20). Moreover, its nutritional composition of about $20 \%$ proteins, $1.4 \%$ crude fat (34) favours its consumption as a 'healthy food'.

Besides proximate composition and size (22), the weakness of the connective tissue, the $\mathrm{pH}$ values and the high moisture content contribute decisively to accelerate spoilage due to (enzyme-induced) autolysis, lipid oxidation and microbiological growth and to make seafood highly perishable $(10,15,43)$.

During frozen storage of fish, the growth of microorganisms is inhibited and autolysis is deactivated but evaporation of the water from the fish cells brings about undesirable changes in terms of consumer's acceptability, namely surface drying and dehydration. Moreover, products may suffer from quality loss due to oxidation of lipids or rancidity. These effects are usually and effectively overcome through the application of a thin, uniform layer of ice to the surface of frozen seafood products, either by spraying on water or by immersing in water bath (52).

Many authors have studied the effect of freezing, glazing and thawing methods on quality changes of different fish and crustacean species $(2,6,39,40)$ namely whiting (5), eel (12), shrimp (17), anchovies (31), mackerel (35), pink salmon (41), chub mackerel (46), rainbow trout (51).

The thawing method of frozen seafood has great importance to maintain the quality (23). If the thawing process is performed correctly there should be little effect on the quality of the product. As a rule, thawing process should be carried out as quickly as possible to prevent off-products from the microbial growth and preserve the sensory characteristic of the food. In addition, the thawing method should avoid the unwarranted heating of seafood, excessive drip loss and dehydration. Several 
methods of thawing fish have been reported namely thawing in still air, air blast thawing, water thawing, vacuum thawing, electrical methods and high pressure thawing $(6,5,27)$.

As it took a significant place at retail level and aquaculture systems and also has high potential for the consumers in terms of the nutritional quality, there is need to understand and clarify the quality changes of meagre fillets after freezing and thawing process. In this study, determination of the effects of different thawing methods on the quality of meagre fillets namely, total volatile basic nitrogen (TVB-N), $\mathrm{pH}$, colour, texture, counts of psychrophilic bacteria, $\mathrm{H}_{2} \mathrm{~S}$-producing bacteria and total viable count (TVC) and estimation of the most suitable thawing method for frozen meagre fillets were aimed.

\section{Materials and Methods}

Materials: Meagre used in the current study (average weight $1596.1 \mathrm{~g} \pm 257.9 \mathrm{~g}$ ) were obtained from the commercial circuit after 6 hours of harvest at retail in Faro, Portugal. The fishes were kept in polystyrene boxes with ice and immediately transported to the laboratory. After filleting the specimens, total 14 fillets $(325.1 \pm 74.1$ g) were washed with tap water.

Freezing and Glazing processes: Fillets were individually and rapidly frozen in a blast and fluid bed freezer (Armfield Ltd, England), until core temperature reached to $-20^{\circ} \mathrm{C}$. Freezing rate was calculated according to the guidelines of International Institute of Refrigeration (1986) (25) by using the following equation;

$$
\mathrm{T}(\mathrm{t})=\mathrm{T}_{\mathrm{a}}+\left(\mathrm{T}_{0}-\mathrm{T}_{\mathrm{a}}\right) \mathrm{e}^{-k t}
$$

where, $\mathrm{T}_{0}$ represents initial temperature of the fillets, $\mathrm{T}_{\mathrm{a}}$ donates the temperature of the ambient, $\mathrm{T}(\mathrm{t})$ is the final temperature at time $\mathrm{t}, \mathrm{k}$ is the constant of the equation and finally $t$ is the time required for to reach to final temperature.

Afterwards, fillets were glazed by immersion them in a container of cold water $\left(0.2\right.$ to $\left.0.4{ }^{\circ} \mathrm{C}\right)$ for 30 seconds and then stored at $-20{ }^{\circ} \mathrm{C}$ for 21 days to simulate the realistic retail conditions.

Thawing methods: Meagre fillets were thawed in the refrigerator $\left(+4{ }^{\circ} \mathrm{C}\right.$ for $\left.6 \mathrm{~h}\right)$, in the air at ambient temperature $\left(+16{ }^{\circ} \mathrm{C}\right.$ for $\left.3.5 \mathrm{~h}\right)$, in water $\left(+16{ }^{\circ} \mathrm{C}\right.$ for 5 min. within polyethylene zipper locked bags), and in microwave oven (for $15 \mathrm{~min}$ at ca. $90 \mathrm{~W}$ ) at defrost option to avoid from the cooking.

Physical analysis: Colour measurements were carried out directly on fresh and thawed samples using a tristimilus colorimeter (DR LANGE, Spectro-color, Spain) and the Hunter L,a,b colour scale (Hunter Associates Laboratory Inc., USA) where L refers to lightness ( 0 is black and 100 is white), a indicates greenness $(\mathrm{a}<0)$ or redness $(\mathrm{a}>0)$, and $\mathrm{b}$ measures blueness $(b<0)$ or yellowness $(b>0)$. The three values are needed to completely describe the colour of an object. Hardness, i.e. the force required to attain a deformation of the products' surface, and adhesiveness, i.e. the work necessary to overcome the attractive forces between the surfaces of the food and its container/package/other contacting materials (48) were determined via a compression test. This test was carried out using a texturometer (LFRA Texture Analyzer, Brookfield Engineering Labs Inc., USA) equipped with a $12.7 \mathrm{~mm}$ diameter stainless steel spherical probe which approached the sample at the speed of $1 \mathrm{~mm}^{-1}$ and compressed $5 \mathrm{~mm}$ into the fillets. Measurements (in kgf) were analysed using TexturePro Lite v1.1 software (Brookfield Engineering Labs Inc., USA). Hardness and adhesiveness were calculated as the peak force of the first compression cycle and the negative area after the 5 $\mathrm{mm}$ penetration, respectively.

Chemical analysis: $\mathrm{pH}$ was determined using a digital meter (Glp 21, Crison, Spain) and measured directly from fish flesh. TVB-N was determined according to method of Conway (9).

Microbiological analysis: For all microbiological analysis 10 grams of sample were taken in $90 \mathrm{ml}$ of 0.85 $\%$ peptone water (Merck, Darmstadt, Germany) and homogenised for 60 seconds (Stomacher ${ }^{\circledR}$ 400, Seward Ltd., London, UK).

Appropriate decimal dilutions were prepared and 1 $\mathrm{ml}$ aliquots were inoculated to the Petri dishes. Pour plating technique was used for TVC by using PCA (Scharlau 01-161) and for $\mathrm{H}_{2} \mathrm{~S}$-producing bacteria using Iron agar (37). TVC samples were incubated at $30^{\circ} \mathrm{C}$ for 48 hours and for psychrophilic count Petri dishes were incubated at $6.5^{\circ} \mathrm{C}$ for 10 days (26). For $\mathrm{H}_{2} \mathrm{~S}$-producing bacteria, Petri dishes were incubated at $25^{\circ} \mathrm{C}$ for 72 hours and the black colonies were counted.

Statistical analysis: Mean values of the parameters and \pm standard deviations are reported. The statistical significance of results was evaluated using one-way analysis of variance (ANOVA) and Tukey HSD test was applied for post-hoc multiple comparisons $(13,29)$ as implemented in SPSS ${ }^{\circledR} 16.0$ for Windows (SPSS Inc., Chicago, USA) for each parameter.

\section{Results}

The quality changes of meagre fillets are shown in Table 1, Table 2 and Table 3. In terms of the color changes the samples that were thawed in water had $L$ values similar to fresh samples. Slight differences between the methods were observed for $a$ values. There were no significant differences for $b$ values. The differences between methods for total color changes were also observed for meagre fillets (Table 1). For the physico-chemical changes, $\mathrm{pH}$ was significantly increased for all treatments $(\mathrm{p}<0.05)$. The TVB-N values 
Table 1. Color results of fresh and frozen-glazed-thawed meagre fillets (values are shown as mean and standard-deviation of $n=3$ fillets).

Tablo 1. Taze ve dondurulan-glaze edilen-çözdürülen sarıă̆ız balığı filetolarındaki renk değişim sonuçları (sonuçlar $\mathrm{n}=3$ filetonun ortalama ve standart sapması olarak gösterilmiştir.)

\begin{tabular}{lcccc}
\hline Thawing treatment & $\mathrm{L}$ & $\mathrm{a}$ & $\mathrm{b}$ & $\Delta \mathrm{E}$ \\
\hline Fresh & $47.68 \pm 3.42^{\mathrm{c}}$ & $-1.80 \pm 0.72^{\mathrm{b}}$ & $-4.65 \pm 1.66^{\mathrm{a}}$ & - \\
Air & $43.93 \pm 2.26^{\mathrm{ab}}$ & $-2.33 \pm 0.53^{\mathrm{ab}}$ & $-2.62 \pm 0.84^{\mathrm{b}}$ & $44.08 \pm 2.23^{\mathrm{ab}}$ \\
Refrigerator & $44.99 \pm 1.74^{\mathrm{abc}}$ & $-1.84 \pm 0.35^{\mathrm{b}}$ & $-1.10 \pm 1.22^{\mathrm{b}}$ & $45.06 \pm 1.75^{\mathrm{ab}}$ \\
Water & $46.63 \pm 3.41^{\mathrm{bc}}$ & $-2.60 \pm 0.16^{\mathrm{a}}$ & $-1.51 \pm 1.08^{\mathrm{b}}$ & $46.74 \pm 3.40^{\mathrm{a}}$ \\
Microwave & $42.77 \pm 3.75^{\mathrm{a}}$ & $-2.20 \pm 0.46^{\mathrm{ab}}$ & $-1.90 \pm 2.21^{\mathrm{b}}$ & $42.93 \pm 3.76^{\mathrm{b}}$ \\
\hline ANOVA sig. & $\mathrm{p}=0.000$ & $\mathrm{p}=0.000$ & $\mathrm{p}=0.000$ & $\mathrm{p}=0.012$ \\
\hline
\end{tabular}

L: lightness ( 0 is black and 100 is white)

a: green $(a<0)$ and red $(a>0)$

b: blue $(b<0)$ and yellow $(b>0)$

$\Delta \mathrm{E}$ : indicates the total colour changes

In each column, values with different letters are significantly different $(\mathrm{p}<0.05)$

L: parlaklik (0 siyah ve 100 beyaz)

a: yeşil $(a<0)$ ve kırmızı $(a>0)$

b: mavi $(b<0)$ ve sarı $(b>0)$

$\Delta \mathrm{E}$ : toplam renk değişimlerini ifade etmektedir

Herbir sütunda farklı harfler ile ifade edilen değerler arasındaki farklar önemlidir $(\mathrm{p}<0.05)$

Table 2. pH, TVB-N, hardness and adhesiveness results of fresh, frozen-glazed-thawed meagre fillets (values are shown as mean and standard-deviation of $n=5$ except for TVB-N, where $n=3$ )

Tablo 2. Taze ve dondurulan-glaze edilen-çözdürülen sarıăız balığı filetolarındaki ph, TVB-N, sertlik ve yapışkanlık sonuçları (sonuçlar $n=3$ olan TVB-N dışında $n=5$ örneğin ortalaması ve standart sapması olarak gösterilmiştir).

\begin{tabular}{lcccc}
\hline Thawing treatment & $\mathrm{pH}$ & $\begin{array}{c}\text { TVB-N } \\
(\mathrm{mg} \mathrm{N} / 100 \mathrm{~g})\end{array}$ & $\begin{array}{c}\text { Hardness } \\
\text { (kgf) }\end{array}$ & $\begin{array}{c}\text { Adhesiveness (x10-3 } \\
\text { kgf) }\end{array}$ \\
\hline Fresh & $6.48 \pm 0.10^{\mathrm{a}}$ & $14.99 \pm 1.14^{\mathrm{b}}$ & $0.184 \pm 0.051^{\mathrm{a}}$ & $-2.21 \pm 1.01^{\mathrm{a}}$ \\
Air & $7.29 \pm 0.05^{\mathrm{b}}$ & $12.48 \pm 1.83^{\mathrm{ab}}$ & $0.186 \pm 0.081^{\mathrm{a}}$ & $-1.88 \pm 0.76^{\mathrm{a}}$ \\
Refrigerator & $7.25 \pm 0.06^{\mathrm{b}}$ & $10.29 \pm 0.68^{\mathrm{a}}$ & $0.417 \pm 0.190^{\mathrm{c}}$ & $-2.32 \pm 0.69^{\mathrm{a}}$ \\
Water & $7.65 \pm 0.06^{\mathrm{c}}$ & $10.39 \pm 1.38^{\mathrm{a}}$ & $0.332 \pm 0.091^{\mathrm{bc}}$ & $-2.15 \pm 0.57^{\mathrm{a}}$ \\
Microwave & $7.23 \pm 0.09^{\mathrm{b}}$ & $11.41 \pm 0.39^{\mathrm{a}}$ & $0.208 \pm 0.077^{\mathrm{ab}}$ & $-1.59 \pm 0.33^{\mathrm{a}}$ \\
\hline ANOVA sig. & $\mathrm{p}=0.000$ & $\mathrm{p}=0.000$ & $\mathrm{p}=0.000$ & $\mathrm{p}=0.029$ \\
\hline
\end{tabular}

In each column, values with different letters are significantly different $(\mathrm{p}<0.05)$.

Her bir sütunda farklı harfler ile ifade edilen değerler arasındaki farklar önemlidir $(\mathrm{p}<0.05)$

Table 3. Microorganisms count (LOG CFU/G) of fresh and frozen-glazed-thawed meagre fillets (values are shown as mean and standard-deviation of duplicates, $n=2)$.

Tablo 3. Taze ve dondurulan-glaze edilen-çözdürülen sarıăız balığı filetolarındaki mikroorganizma sayıları (sonuçlar $n=2$ örneğin iki tekrarlı ortalama ve standart sapması olarak gösterilmiştir)

\begin{tabular}{lccc}
\hline Thawing treatment & Total mesophilic aerob bacteria & Total psychrophilic aerob bacteria & $\mathrm{H}_{2} \mathrm{~S}$ producing bacteria \\
\hline Fresh & $3.77 \pm 0.12^{\mathrm{a}}$ & $3.11 \pm 0.02^{\mathrm{a}}$ & $\mathrm{Nd}$. \\
Air & $4.62 \pm 0.33^{\mathrm{b}}$ & $4.48 \pm 0.01^{\mathrm{d}}$ & $\mathrm{Nd}$. \\
Refrigerator & $3.55 \pm 0.008^{\mathrm{a}}$ & $3.41 \pm 0.01^{\mathrm{b}}$ & $\mathrm{Nd}$. \\
Water & $4.10 \pm 0.16^{\mathrm{ab}}$ & $3.91 \pm 0.07^{\mathrm{c}}$ & $\mathrm{Nd}$. \\
Microwave & $3.85 \pm 0.01^{\mathrm{ab}}$ & $3.34 \pm 0.07^{\mathrm{b}}$ & $\mathrm{Nd}$. \\
\hline ANOVA sig. & $\mathrm{p}=0.007$ & $\mathrm{p}=0.000$ & $\mathrm{p}=-$ \\
\hline
\end{tabular}

Nd. Not-detected

In each column, values with different letters are significantly different $(\mathrm{p}<0.05)$.

Her bir sütunda farklı harfler ile ifade edilen değerler arasındaki farklar önemlidir $(\mathrm{p}<0.05)$ 
were found lower in refrigerator and water thawed samples compared to other treatments. At the end of the storage hardness of the fillets were found higher compared to fresh samples. No significant differences were found between treatments for adhesiveness values (Table 2). The lowest total viable counts were obtained in refrigerator thawed samples $(3.55 \pm 0.008 \log \mathrm{cfu} / \mathrm{g})$. The counts of psychrophilic bacteria were lower for microwave thawing $(p>0.05)$ compared to refrigerator thawed samples. $\mathrm{H}_{2} \mathrm{~S}$ producing bacteria were not detectable in all samples. Regarding to the results of this study, refrigerator thawing was found the most suitable method for frozen meagre fillets. Moreover, by taking into account that meagre is one of the alternative fish species for seafood markets and new for the consumers in Turkey and Europe, present study could have remarkable importance for thawing the meagre fillets after transportation.

\section{Discussion and Conclusion}

Freezing process: Figure 1. shows the core and ambient temperatures of meagre fillets during freezing process. The initial and final temperature were taken $8^{\circ} \mathrm{C}$ (temperature of the fillets) and $-25^{\circ} \mathrm{C}$ final core temperature for calculating the freezing rate. Moreover, freezing rate $(n=3)$ was found to be $-0.019 \pm 0.02{ }^{\circ} \mathrm{C} / \mathrm{min}$ (Fig 1.). In another study freezing rate of conventionally air frozen Atlantic salmon fillets was notified to be $0.112 \pm 0.005^{\circ} \mathrm{C} / \mathrm{min}$ (54). This variation may be the result of differences between species and indicating that the proper freezing was applied to the fillets tested.

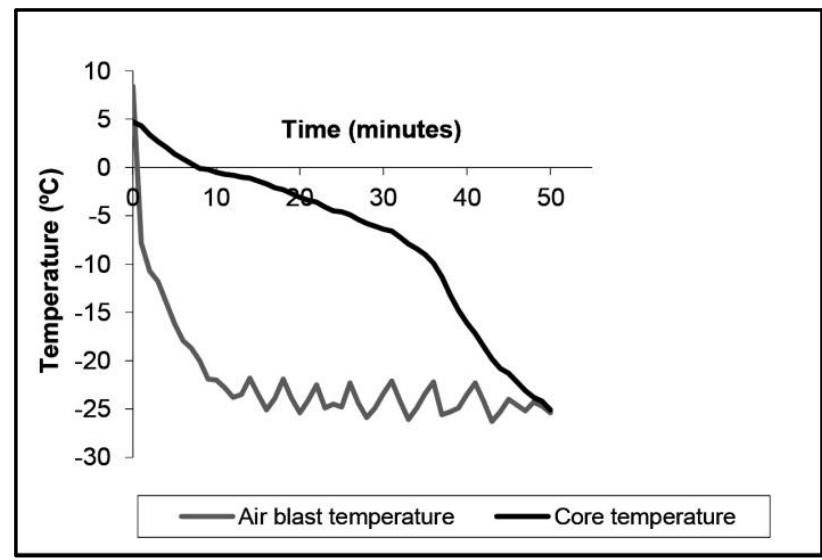

Figure 1. Temperature profiles of meagre fillets durıng freezıng process.

Şekil 1. Dondurma işlemi süresince sarıăız filetolarının sıcaklık profilleri.

Physical and Chemical analysis: Colour changes between thawing methods are shown in Table 1 . Significant differences were found for $\mathrm{L}$ and a values. The fillets thawed using the microwave oven were darker, i.e. had lowest $\mathrm{L}$ values comparing to the others.
The lowest a values were recorded for fillets thawed in water bath while the highest values were measured in samples thawed in the refrigerator. Differences between these two (extreme) values were significant $(p<0.05)$. In general, fillets became darker, somewhat greener and were less bluish than the control, fresh fillets, after thawing.

Conversely, there were no significant differences between $b$ values among thawing methods but all thawed fillets were less bluish (i.e. higher values of $b$ ) than fresh samples. In contrast to our results, Ersoy et al. (2008) reported that the highest a values was observed in the water thawed of eel (Anguilla anguilla). This differences between these two species showing that fat content of the species are also playing a significant role in the thawing of the samples. Colour changes resulting from thawing treatments are expecting due to microbiological and chemical induced losses of quality. Also colour changes are seemingly influenced by the temperature (42) and dynamics of thawing conditions. Moreover, "discoloration" of whole fish is one of the quality parameters that is included in almost all freshness assessment schemes for seafood and fish $(4,47)$.

The $\mathrm{pH}$ of the muscle of fresh fish is close to neutrality. However, mostly as a result of the anaerobic fermentation of fish tissues which brings about the lactic acid production, the $\mathrm{pH}$ of fish tissue gradually decreases (21). In our study, initial value of the $\mathrm{pH}$ was $6.48 \pm 0.10$ for the fresh fillets (Table 2) and after glazing-thawing processes the value was increased significantly for every treatment tested $(\mathrm{p}<0.05)$. The increase or decrease of $\mathrm{pH}$ in seafood tissues is related to the dominant biochemical pathway during spoilage. If the deterioration is caused by anaerobic bacteria, then $\mathrm{pH}$ will decrease due to the production of lactic acid. Conversely, $\mathrm{pH}$ increases if the spoilage process leads to the production of biogenic amines, most of which have basic characteristics (30).

$\mathrm{pH}$ values were highest for water thawed samples, $7.65 \pm 0.06$. Other treatments did not differ significantly. Sathivel et al. (2007) reported that the initial $\mathrm{pH}$ of raw non-glazed pink salmon (Oncorhynchus gorbuscha) fillets was 6.63 which is similar to our results for the initial $\mathrm{pH}$ of the fillets. Tokur et al. (2008) evaluated the effects of thawing in running water, microwave and room temperature on protein quality of rainbow trout (Oncorhynchus mykiss) and sardine (Sardina pilchardus). Comparing with our results the $\mathrm{pH}$ values of rainbow trout and sardine were lower. This differences could be concluded that after thawing the species with high fat content such as sardine, could induce $\mathrm{pH}$ decrease as a result of oxidation if the proposed thawing method is not proper. Nonetheless, they found the highest values of $\mathrm{pH}$ for rainbow trout and sardine thawed in the running water which is similar to results that we observed. 
One of the quality parameters of the glazed-thawed meagre was determination of volatile bases. TVB-N values of fresh meagre fillets were found to average $14.99 \pm 1.14 \mathrm{mg} \mathrm{N} / 100 \mathrm{~g}$ sample. The observed results are lower than those of fresh meagre fillets reported by Hernández et al. (2009), $20.4 \pm 0.97$ mg N/100 g sample. After application of the thawing treatments the values of TVB-N were decreased significantly when compared to the fresh samples $(\mathrm{p}<0.05)$ (Table 2). For the refrigerator, water and microwave oven-thawed fillets, the values of TVB-N varied from $10.29 \pm 0.68$ to $11.41 \pm 0.39 \mathrm{mg}$ $\mathrm{N} / 100 \mathrm{~g}$, but there were no significant differences between those treatments. Fillets thawed exposed to air had TVB-N values of $12.48 \pm 1.83 \mathrm{mg} \mathrm{N} / 100 \mathrm{~g}$, lower than those of fresh samples but higher than other methods, although not significantly.

TVB-N is good indicator for advanced spoilage but is an insufficient sign of quality during the initial stages of the seafood spoilage (7). In addition, TVB-N values vary from species to species; the acceptable limits of TVB-N reported in the literature are in the range 30-35 $\mathrm{mg} \mathrm{N} / 100 \mathrm{~g}(21,32)$. In contrast to our study, Ersoy et al. (2008) found the lowest TVB-N values by thawing eel fillets exposed to air. In another study Turan et al. (2006), found the highest TVB-N values for whole rainbow trout (Oncorhynchus mykiss) by thawing in the refrigerator comparing to microwave, water and airthawed fish and the values averaged $14.49 \mathrm{mg} \mathrm{N} / 100 \mathrm{~g}$. Mol et al. (2004) stated that the TVB-N values of the airthawed whole mackerel (Scomber scombrus) which were bought from the first depot were higher than the waterthawed ones. Our results are found to be similar with the latest study and indicating that fillets are maintaining the freshness.

In terms of fillets' texture, differences between treatments regarding adhesiveness were not significant $(p>0.05)$. In contrast, hardness was significantly increased $(p<0.05)$ in the refrigerator and water thawed fillets (Table 2). Sigurgisladottir et al. (1999) reported that thickness is one of the factors which can cause the increase in hardness. In the mentioned study, they found that hardness increased from head to tail in salmon fillets. In a concurrent study (16), the author also found that there were differences in hardness in anterior versus posterior portions of meagre fillets stored at chilled $(+4$ ${ }^{\circ} \mathrm{C}$ ) temperature. For the water thawing the thickness of fillets were relatively thinner than the others (data not shown) and hence the increased hardness. The highest value of hardness, $0.417 \pm 0.190 \mathrm{kgf}$, was obtained in the refrigerator-thawed fillets. Moreover, fillets were considered completely thawed when there was no ice cover, a condition that occurred when their core temperature reaches $-1{ }^{\circ} \mathrm{C}$. After five hours of thawing in the refrigerator, core temperature of the meagre fillets did not exceed $-1.5{ }^{\circ} \mathrm{C}$. This study showed that thawed meagre fillets were harder than fresh ones. These results were observed many times on fish fillets that is mainly due to the loss of water-holding capacity, partly owing to mechanical damage and protein denaturation induced by the freezing-thawing cycle $(1,3,14)$. Tseng et al. (2003), have studied the effect of multiple freezing-thawing cycles on the quality of Australian red claw crayfish (Cherax quadricarinatus). They found that shear force was increased rapidly after freezing-thawing process and concluded this phenomenon as a result of damaged tissue of muscle as influenced by freezing thawing cycles. These results are similar with our findings and concluded that the thawing process could cause decreased water holding capacity and increased hardness even though at low temperatures.

Microbiological analysis: The changes in the microbiota of thawed meagre fillets are shown in Table 3. Total viable counts (TVC) and psychrophilic bacteria counts in fresh meagre fillets were found to be $3.77 \mathrm{log}$ cfu/g and $3.11 \log \mathrm{cfu} / \mathrm{g}$, respectively. These results are in line with those of Hernández et al. (2009) for fresh meagre fillets, namely $3.11 \mathrm{log} \mathrm{cfu} / \mathrm{g}$ and $2.82 \mathrm{log} \mathrm{cfu} / \mathrm{g}$, respectively. The growth of micro-organism is halted at temperatures below $-10^{\circ} \mathrm{C}$ thus frozen fish has fewer bacteria than fresh fish $(8,45)$ but, depending on the method used, bacteria resume growth during thawing $(23,27)$. In this study, the lowest TVC and psychrophilic counts were found to be $3.55 \mathrm{log} \mathrm{cfu} / \mathrm{g}$ and $3.41 \mathrm{log}$ cfu/g, respectively, after thawing the fillets in the refrigerator. The refrigerator temperature was expected to slow down the TVC, however can support the psychrophilic bacteria number. For TVC and counts of psychrophilic bacteria the differences between treatments are significant $(\mathrm{p}<0.05)$. Highest TVC and counts of psychrophilic bacteria were found in air-thawed samples. Seemingly, prolonged thawing duration at higher temperatures increases the growth of microorganisms. This study also showed that method-specific conditions favour differently the growth of microorganisms. Moreover, results of the $\mathrm{H}_{2} \mathrm{~S}$-producing bacteria counts were undetectable in all treatments, including the fresh samples.

The TVC results of refrigerator-thawed fillets were found lower than those of Ersoy et al. (2008). Javadian et al. (2013) have studied quality attributes of thawed whole rainbow trout (Onchorhynchus mykiss) which were frozen. In terms of TVC and counts of psychrophilic bacteria our results were lower compared to the results of rainbow trout after all thawing treatments. This may be concluded the differences between species but mainly the initial values of microorganisms. Even though the differences are significant between the treatments and fresh fillets in our study, the fish fillets are in good condition and do not pose a health threat to consumers after thawing (24). All of the thawing treatments gave 
non-detectable values for $\mathrm{H}_{2} \mathrm{~S}$-producing bacteria. Some of these bacteria are capable of reducing trimethylamine $\mathrm{N}$-oxide (TMAO) and also degrading sulphur-containing amino acids and producing volatile sulphides including $\mathrm{H}_{2} \mathrm{~S}(18,33,53)$. A number of these bacteria, namely Shewanella putrefaciens, pose health risk and have been shown to be inversely related to the remaining shelf-life of seafood products (18). Additionally in this study, no contamination from the thawing methods was observed, referring to the results of $\mathrm{H}_{2} \mathrm{~S}$ producing bacteria.

Thawing methods tested in this study, had significant effect on the physical, chemical and microbiological quality of meagre fillets. The lowest total viable count, TVB-N and values of a (colour) were observed in refrigerator-thawed fillets. Moreover, $\mathrm{H}_{2} \mathrm{~S}$ producing bacteria were not detected in any of the thawing methods. The effects observed in this study contribute positively to consumers' acceptability of the product. As an advice, to prevent the product from airborne microbial contamination, surfaces of product should be covered. For thawing the meagre fillets, the use of the refrigerator at appropriate power was found the most suitable method of those tested herein. Notwithstanding, detailed studies are needed to clarify the effect of refrigerator thawing duration given that herein after $5 \mathrm{~h}$ fillets' core temperatures did not exceed $1.5^{\circ} \mathrm{C}$.

\section{References}

1. AlizadehE, Chapleau N, De Lamballerie M, LeBail A (2007): Effects of freezing and thawing process on the quality of Atlantic salmon (Salmo salar) fillets. J Food Sci. 72: $279-284$

2. Baygar T, Özden Ö, Üçok D (2004): Dondurma ve çözündürme işleminin balık kalitesi üzerine etkisi. Turk J Vet Anim Sci. 28: 173-178

3. Benjakul S, Bauer F (2001): Biochemical and physicochemical changes in catfish (Silurus glanis Linne) muscle as influenced by different freeze-thaw cycles. Food Chem. 72:207-217

4. Bonilla A. C, Sveinsdottir K, Martinsdottir E (2007): Development of quality index method (QIM) scheme for fresh cod (Gadus morhua) fillets and application in shelf life study. Food Control. 18: 352-35

5. Chevalier D, Lebail A, Chourot J M, Chantreau $\mathbf{P}$ (1999): High pressure thawing of fish (whiting): influence of the process parameters on drip losses. Leb Wiss Tech. 32: $25-31$.

6. Chourot JM, Boillereaux L, Havet M, Lebail A (1997): Numerical modelling of high pressure thawing: application to water thawing. J Food Eng. 34: 63-75.

7. Clancy GS, Bearnes DA, Higgs DA, Dosanjh BS (1995): Effect of methodology on the determination of total volatile nitrogen and trimethylamine levels in previously frozen Pacific herring (Clupea harengus pallasi) stored at $2-5^{\circ} \mathrm{C}$ for up to 15 days. Canadian Technical Report of Fisheries and Aquatic Science, 2047,10p.
8. Connel JJ (1995). Control of fish quality, $4^{\text {th }}$ Edition, Cambridge, UK: Cambridge University Press, $256 \mathrm{p}$.

9. Conway EJ, Byrne A (1933): An absorption apparatus for the micro - determination of certain volatile substances. I. The micro - determination of ammonia. Biochem J. 27: $419-429$.

10. Demirci M, Orak HH (1995). Farklı soğutma ortamlar ve $-12{ }^{\circ} C^{\prime}$ de depolanan istavrit balı̆gnda (Trachurus trachurus) meydana gelen kalite değişimleri. Turk J Agric For. 23: 143-150.

11. El-Shebly AA, El-Kady MA H, Hussin AB, Hossain Md Y (2007): Preliminary observations on the pond culture of meagre, Argyrosomus regius (Asso, 1801) (Sciaenidae) in Egypt. J Fish Aquat Sci. 2: 345-352.

12. Ersoy B , Aksan E. Ozeren A (2008): The effect of thawing methods on the quality of eels (Anguilla anguilla). Food Chem. 111: 377-380.

13. Esteves E (2010): Statistical analysis in food science. In: Practical Food and Research (Edited by R.M. Cruz). NY, USA: Nova Science Publishers Inc.

14. Farmer LJ, McConnell JM, Kilpatrick DJ (2000) Sensory characteristics of farmed and wild Atlantic salmon. Aquaculture.187: 105-125.

15. Frazier WC, Westhoff DC (1988): Food Microbiology, Singapore, McGraw-Hill Book Company, Forth Edition, 539p.

16. Genç IY (2012): Microbiological, chemical, physical changes of meagre fillets under chilled $\left(+4^{\circ} \mathrm{C}\right)$ conditions. MSc. Thesis (In Turkish with English abstract) 56p.

17. Gonçalves A A. Junior CSGG (2009): The effect of glaze uptake on storage quality of frozen shrimp. J Food Eng. 90: 285-290.

18. Gram L, Huss HH (1996): Microbiological spoilage of fish and fish products. Int J Food Microbiol. 33: 121-137.

19. Griffiths M H. Heemstra PC (1995): A contribution to the taxonomy of the marine fish genus argyrosomus (Perciformes: Sciaenidae), with descriptions of two new species from southern Africa. Ichthyological Bulletin of the JLB Smith Institute of Ichthyology, 65: 1-40.

20. Hernández MD, López MB, Álvarez A, Ferrandini E, García B G, Garrido MD (2009): Sensory, physical, chemical and microbiological changes in aquacultured meagre (Argyrosomus regius) fillets during ice storage. Food Chem. 114: 237-245.

21. Huss H H (1988): Fresh fish-quality and quality changes, FAO Fisheries Series No.29, Rome: FAO, 40 p.

22. Huss HH (1995): Quality and quality changes in fresh fish. FAO Fisheries Technical Paper, 348, 195 p.

23. Inal T (1992): Besin hijyeni hayvansal gidalarin sağlık kontrolü, İstanbul - Final press, 783p.

24. ICMSF (1986): Sampling plans for fish and shellfish. In: Microorganisms in Foods. Sampling for Microbiological Analysis: Principles and Scientific Applications (edited by ICMSF), 2nd Edition, pp. 181-196. Toronto, Canada: University of Toronto Press.

25. International Institute of Refrigeration (1986): Recommendations for the processing and handling of frozen foods (3rd ed.) (pp 32-39). Paris: International Institute of Refrigeration.

26. ISO (2003): ISO 4833 Microbiology of food and animal feeding stuffs - horizontal method for the enumeration of 
microorganisms - Colony-count technique at $30^{\circ} \mathrm{C}$, Genève, Switzerland: International Organization for Standardization, $9 \mathrm{p}$.

27. Jason AC (1974): Thawing frozen fish, ministry of agriculture, fisheries and food, Torry Advisory Note No.25, Torry Research Station.

28. Javadian SR, Rezaei M, Soltani M, Kazemian M. Pourgholam R (2013): Effects of thawing methods on chemical biochemical and microbial quality of frozen whole rainbow trout (Oncorhynchus mykiss). J Aqua Food Prod Tech. 22:168-177.

29. Johnson RA. Wichern DW (1998): Applied Multivariate Statistical Analysis, 4th Edition, New Jersey, USA: Prentice-Hall Inc, 816p.

30. Jørgensen LV, Dalgaard P. Huss HH (2000): Multiple compound quality index for cold-smoked salmon (Salmo salar) developed by multivariate regression of biogenic amines and pH. J Agr Food Chem. 48: 2448-2453.

31. Karacam H, Boran M (1996): Quality changes in frozen whole and gutted anchovies during storage at $-18^{\circ} \mathrm{C}$. Int $\mathrm{J}$ Food Sci Tech. 31: 527-531.

32. Kim MY, Joeng WS. Chung SK (2002): The physicochemical quality characteristics of charcoal grilled mackerels. J Food Sci. 67: 1255-1259.

33. Koutsoumanis K, Nychas GJE (1999): Chemical and sensory changes associated with microbial flora of Mediterranean boque (Boops boops) stored aerobically at 0, 3, 7, and $10^{\circ} \mathrm{C}$. Appl Environ Microb. 65: 698-706.

34. Martins I, Porto A, Oliveira L (2006): Tabela de Composição de Alimentos, pp. 56-57, Lisboa, Portugal: Instituto Nacional de Saúde Dr. Ricardo Jorge.

35. Mol S, Ozden O, Erkan N, Baygar T (2004): İthal uskumruların değişik çözülme koşullarındaki kalite parametrelerinin belirlenmesi Turk J Vet Anim Sci. 28: 1071-1077.

36. Monfort MC (2010): Present market situation and prospects of meagre (Argyrosomus regius), as an emerging species in Mediterranean aquaculture, Studies and Reviews, General Fisheries Commission for the Mediterranean, 89, Rome: FAO: 28p.

37. NMKL. (2006): NMKL method No. 184, Aerobic count and specific spoilage organisms in fish and fish products. Espoo, Finland: Nordic Committee on Food Analysis, pp $1-6$.

38. Poli BM, Parisi G, Zampacavallo G, Iurzan F, Mecatti M, Lupi P, Bonelli A (2003): Preliminary results on quality and quality changes in reared meagre (Argyrosomus regius): body and fillet traits and freshness changes in refrigerated commercial-size fish. Aquacult Int. 11: 301-311.

39. Popelka P, Šoltýsová S L (2008): Effect of glazing on oxidative changes of fish stored at stable and unstable freezing conditions. Acta Sci Pol. Medicina Veterinaria 7: 23-28.

40. Rouille J, Lebail A, Ramaswamy HS, Leclerc L (2002): High pressure thawing of fish and shellfish. J Food Eng. 53: $83-88$.

41. Sathivel S, Liu Q, Huang J, Prinyawiwatkul W (2007): The influence of chitosan glazing on the quality of skinless pink salmon (Oncorhynchus gorbuscha) fillets during frozen storage. J Food Eng. 83: 366-373.
42. Schubring R, Meyera C, Schluterb O, Boguslawskib S, Knorr D (2003): Impact of high pressure assisted thawing on the quality of fillets from various fish species. Innov Food Sci Emerg Tech. 4: 257-267.

43. Serdaroğlu M, Deniz EE (2001): Balıklarda ve bazı su ürünlerinde trimetilamin ve dimetilamin oluşumunu etkileyen faktörler. Ege Üniv Su Ürün Derg. 18: 575-581.

44. Sigurgisladottir S, Hafsteinsson H, Jonsson A, Lie Ø, Nortvedt R, Thomassen M, Torrissen O (1999): Textural properties of raw salmon fillets as related to sampling method. J Food Sci. 64: 99-104.

45. Sikorski ZE (1990): Seafood: Resources, Nutritional Composition, and Preservation, Boca Raton, Florida: CRC Press Inc. 248 p.

46. Soyer A, Sahin ME (1999): Dondurulmuş kolyoz (Scomber japonicus) balıklarındaki lipid oksidasyonuna glazelemenin ve depolama süresinin etkisi. Turk $\mathrm{J}$ Vet Anim Sci. 23: 575-584.

47. Sveinsdottir K, Hyldig G, Martinsdottir E, Jørgensen B, Kristbergsson K (2003): Quality Index Method (QIM) scheme developed for farmed Atlantic salmon (Salmo salar). Food Qual Prefer. 14: 237-245

48. Szczesniak AS (2002): Texture is a sensory property. Food Qual Prefer. 13: 215-225.

49. Tokur B, Kandemir S (2008): Dondurulmuş balıklarda farklı çözündürme şekillerinin protein kalitesine olan etkileri. J Fisheries Sci 2: 100-106

50. Tseng YC, Xiong YL, Feng J, Ramirez-Suarez JC (2003): Quality changes in Australian red claw crayfish (Cherax quatricarinacus) subjected to multiple freezingthawing cycles. J Food Qual. 26:285-298.

51. Turan H, Kaya Y, Erdem M E, Sönmez G, Kodalak N, Erkoyuncu I (2006): Donmus alabalikların kalitesi üzerine farklı çözdürme koşullarının etkisi. İstanbul Üniv Su Ürün Derg. 20: 21-32.

52. Vanhaeckea L, Verbeke W, Brabander HFD, (2010): Glazing of frozen fish: analytical and economic challenges. Anal Chim Acta. 672: 40-44.

53. Vogel BF, Venkateswaran K, Satomi M, Gram L (2005): Identification of Shewanella baltica as the Most Important $\mathrm{H}_{2} \mathrm{~S}$-Producing Species during Iced Storage of Danish Marine Fish. Appl Environ Microb. 71: 11 66896697.

54. Zhu S, Ramaswamy H S, Simpson BK (2004): Effect of high-pressure versus conventional thawing on color, drip loss and texture of Atlantic salmon frozen by different methods. Lebensm -Wiss u- Technol. 37:291-299.

Geliş tarihi: 25.12.2013/ Kabul tarihi: 12.06.2014
Address for correspondence:
Research Assistant İsmail Yüksel Genç,
University of Süleyman Demirel,
Faculty of Fisheries,
Department of Fishing and Processing Technology,
Isparta, Turkey.
e-mail: ismailgenc@sdu.edu.tr and
ismailygenc@gmail.com 